\title{
Small Business Entrepreneurships In The United States
}

RamMohan R. Yallapragada, Fayetteville State University, USA Mohammad Bhuiyan, Fayetteville State University, USA

\begin{abstract}
A small business entrepreneur is defined as an individual who establishes and manages a business for the principal purpose of profit and growth. Small businesses constitute an increasingly large proportion of businesses generally in the United States' economy. They account for 39 per cent of the United States' gross national product and create two out of every three new jobs in our economy. Seven important prerequisites are identified as being necessary for successfully operating a small business. These include adequate financing, qualified personnel, efficient operation and production, marketing and sales, customer service, information management and administration. One of the most significant contributors to failure of a small business relates to acquisition of adequate capital. Small Business Administration (SBA) was established by Federal Government in 1953 to provide low interest loans to small business borrowers that would not otherwise have access to credit. However, there is some criticism that these SBA programs unfairly benefit, not the small businesses, but the financial institutions that participate in the SBA loan programs. Another significant source of debt financing to small businesses is known as 'micro-financing,' started as new wave in providing capital to small businesses by the Nobel Peace Prize winner, Muhammad Yunus, in Bangladesh.
\end{abstract}

Keywords: Small Business; Entrepreneurships; Small Business Administration; Micro-Financing

\section{INTRODUCTION}

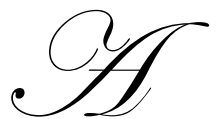

t present, there are nearly 27 million small business firms in the United States and these are the strength of our economy. As Headd (2010) observes, they account for 39 per cent of the United States' gross national product, create two out of every three new jobs and produce two and a half times as many innovations per employee as do large business firms. As Quinn (1997) states, small businesses constitute an increasingly large proportion of businesses generally in the United States. A small business entrepreneur is defined as an individual who establishes and manages a business for the principal purpose of profit and growth (Carland et al., 1984). Some authors in the $18^{\text {th }}$ century identified the entrepreneur as "an individual operating with self-interest, having the foresight and willingness to assume risk, and by opportunistic action, making a profit or sustaining loss. Risk tolerance, in consideration for economic profit, is a consistent element in all early theories of entrepreneurship" (Hebert and Link, 1982). The 27 million small business organizations in the United States, accounting for nearly 99.7 per cent of employer businesses (SBA, 2009). Small businesses also tend to fill niches in the labor market that are under-represented, with high rates of unemployment. Small businesses employ higher rates of Hispanics (nearly 66 per cent). Compared with large firms, small businesses also employ higher share of people with low educational levels, individuals 65 or older, disabled workers and rural workers (Headd, 2010). 


\section{HOW IMPORTANT ARE SMALL BUSINESS ENTREPRENEURS TO THE ECONOMY OF THE UNITED STATES?}

According to Kobe (2007), small firms:

1. Represent 99.7 per cent of all employer firms.

2. $\quad$ Employ just over half of all private sector employees.

3. $\quad$ Pay 44 per cent of total United States private business payroll.

4. Have generated 64 per cent of net new jobs over the past 15 years.

5. $\quad$ Create more than half of the non-farm private gross domestic product.

6. Hire over 40 per cent of high-tech workers such as scientists, engineers, and computer programmers.

7. Constitute 97.3 per cent of all identified exporters and produced 30.2 per cent of the known export value in the fiscal year of 2007 .

8. 52 per cent are home-based and 2 per cent, franchises

Source: Kobe, Kathryn (2007). Office of Advocacy funded research, U. S. Department of Commerce, Bureau of Census and International Trade Administration (2007).

\section{GENDER ISSUES IN SMALL BUSINESS ENTREPRENEURS}

Women represent more than one third of all people involved in entrepreneurial activity. Between 1997 and 2002, women-owned firms grew by 19.8 percent while all U. S. firms grew by seven percent (SBA, Office of Advocacy, 2005). But, in spite of their growth, the firm performance is reported lower in female-owned firms as compared with male-owned firms. Swinney, Runyan and Huddleston (2006) also conducted a study on the differences in reported firm performance by gender, among small business entrepreneurs. In the overall sample of 267 retail and service businesses, mean performance scores were higher in male-owned firms than in female-owned firms. Over 50 per cent of all small business firms in the United States economy are in the retail and service sectors. More than 83 per cent of all female-owned businesses in the United States operate in these retail and service sectors, whereas only 63 per cent of all male-owned small business firms operate in the same sectors (SBA, 2003).

\section{FACTORS FOR SUCCESS}

Robinson et al. (2007) bemoan that, "it is a jungle out there for small business owners." It is reported that nearly 34 per cent of new small businesses do not survive the first two years.

According to Brown (2007), the average number of small businesses opening each year is approximately the same as the number of small business firms closing in that year. Brown (2007) lists seven basic skills recommended by SBA as prerequisites for success of a small business firm. Very few entrepreneurs may possess all these skills, but it is imperative for an entrepreneur to be aware of these necessary skills, and to hire employees to compensate for the missing skills. The recommended skills are listed as follows:

1. Financing: Very few new entrepreneurs realize the extreme importance of adequate finances, which are said to be the heart beat of the business organization. Every new business owner needs to have an understanding of the process of raising funds, management of cash flows, and an understanding of the basic financial statements.

2. Human Resources: Unless it is a single proprietorship, the entrepreneur needs to know what skills are needed in the persons to be hired, where to look for such employees, how to motivate and retain employees once they are hired, and what the optimum level of compensation is to achieve such motivation and retention.

3. Operation and Production: If the business involves production, the owner must have a detailed understanding of the production process, the quality and the quantities of the raw material, skilled labor and other items needed and the management of the costs of production. 
4. Marketing and Sales: It very important to identify one's customers, and then devise ways and means of reaching and retaining them. One has to find the ways of dealing with competing firms.

5. Customer Service: After-sales service to customers is crucial to generate customer loyalty.

6. Information Management: Information management is the life's blood of an organization. It includes locating sources and gathering of information on a continuous basis and providing the necessary information to internal and external users of the information. Effective usage of the latest information technology is an important ingredient of information management.

7. Administration: The most important factor for success of an organization is the administration which encompasses the crucial management functions of planning, directing and controlling the business operations. It involves communication skills, interpersonal skills, leadership, negotiation skills and the realization of the importance of making ethical decisions (Brown, 2007).

Robinson, et., al. (2007) recommend that before launching a new business, the entrepreneur has to conduct the necessary research for starting a new business. The qualities of tenacity, courage and ingenuity are found to be the common factors among successful entrepreneurs. The finalists of David Awards to Heroes of small businesses in New Zealand were found to be "inspiring and courageous business people with a passion for what they do and the determination to make it work. Some of them have overcome considerable adversity in order to reach the success they now enjoy" (Douglas and Martin, 2009).

\section{FREQUENTLY MENTIONED CAUSES OF FAILURE}

From the FASTTRACK Entrepreneurship Training Program offered at Baylor University, Waco, TX, and from a research study conducted by Neubert, Gibson and Longnecker (2004), O'Connell (2004) identified the following ten frequently found causes for failure of small business entrepreneurships.

1. Ineffective communication skills and practices.

2. Poor work relationships and interpersonal skills.

3. Person-job mismatch

4. $\quad$ Failure to provide direction and performance expectations.

5. Breakdown in delegation and empowerment

6. $\quad$ Failure to break old habits.

7. Inability to develop teamwork and cooperation.

8. $\quad$ Lack of personal integrity and trust.

9. Inability to lead and motivate personnel.

10. Poor planning and operational practices.

(Source: O’Connell, 2004).

Financing decisions are among the most challenging and important issues confronting small business entrepreneurs (Berger and Udell, 1998). A small business will not be able to adequately fund its operations and pursue market opportunities if it faces under-capitalization, inappropriate sources of capital and lack of information about capital acquisition (Carter and Van Auken, 2005). According to the financial theory of capital structure, "small business owners should acquire capital in a mix that maximizes wealth by minimizing the firm's cost of capital, through optimal levels of equity and debt (Myers, 1984).

Some of the most frequent contributors to small business failures involve issues relating to the acquisition of capital (Coleman, 2000). Several studies identified that lack of access to capital markets had negative impact on small business firms (Van Auken and Carter, 1989). Approximately half of small business financing is from equity and the other half, from borrowing. Financial institutions and government agencies are the main sources of debt financing. Sources of equity include wealthy individual investors and venture capital investors (Berger and Udell, 1998). Many small business entrepreneurs face problems in obtaining debt capital at costs that are affordable. According to Resnick (2006), "most startups have horror stories about banks that give them the run around--- 
failing to return calls, taking months to approve, or decline, their loan applications, even refusing to let them withdraw their own money.--- it is too easy for startups to entangled in the complex web of large banks' policies and procedures."

\section{MAJOR SOURCES OF FINANCING FOR SMALL BUSINESS ENTREPRENEURS}

In 1953, the Small Business Administration (SBA) was created by the Federal government to help provide low interest loans to small business borrowers that would not otherwise have access to credit. SBA's fiscal year 2009 budget included $\$ 28$ billion in guaranteed loans for small business firms. However, there is some criticism that these SBA programs unfairly benefit, not the small businesses, but the financial institutions that participate in the SBA loan programs (Craig, et al., 2009). De Rugy (2007), a research economist with the American Enterprise Institute, claims that SBA loan programs only provide large subsidies for the financial institutions that are in the SBA's guaranteed lending programs.

Another significant source of debt financing for small business entrepreneurs, an international phenomenon of recent origin, is known as "micro-financing'. Farrell (2006) defines micro-financing as a system for providing small loans, in many cases without the requirement of any collateral, to poor entrepreneurs, typically self-employed and running a home-based small business. The father of micro-financing is Dr. Muhammad Yunus, a professor of economics at the University of Chittagong, Bangladesh. Yunus began to lend funds, small funds, to the women of rural areas of Bangladesh, without any requirement of collateral, to support their cottage industries. Yunus found that some people in the rural areas of Bangladesh are saddled with debt, in small amounts, but with unreasonably high, usurious rates of interest that kept the borrowers as bonded slaves to the money lenders. As Yunus (2008) states, "I came up with a list of 42 people who borrowed a total of (amount equivalent to) \$27. And suddenly it came to my mind--- the problem is enormous, but the solution is simple. I can just go ahead and give (lend) this \$27 to these people and they will be free from the money lenders' bondage. The rest was history." Dr. Yunus was awarded the Nobel Peace Prize in 2006 for his monumental contribution in Grameen Bank and micro-financing.

According to Yunus (2007), the problems confronting small businesses entrepreneurs in obtaining funds for establishing and operating their businesses are world-wide. The problem existing in Bangladesh -- the exclusion of the poor from benefits of the financial system -- is not restricted only to the poorest countries in the world. Even in the richest countries in the world, many people are not considered credit-worthy and are therefore ineligible to participate fully in the economic system (Yunus, 2007).

\section{SUMMARY, CONCLUSION AND RECOMMENDATIONS}

Small business firms constitute a very significant part of the United States economy. They comprise of half of the total private sector employment in the United States with over 44 percent of the private sector payroll. Small business entrepreneurs are tenacious, courageous, independent, and risk-taking people, contributing significantly to the total United States economy. They create more than half of the non-farm private gross domestic product. Small businesses hire over 40 per cent of high-tech workers such as scientists, engineers, computer programmers. Small businesses also tend to fill niches in the labor market that are under-represented, with high rates of unemployment. Small businesses employ higher rates of Hispanics (nearly 66 per cent). Compared with large firms, small businesses also employ higher share of people with low educational levels, individuals 65 or older, disabled workers and rural workers.

In general, in any given year, the number of new small business firms that are started is approximately equal to the ones which are closed due to failure, in the same year. Lack of adequate finances appears to be one of the main causes of failure among small business entrepreneurs. Small Business Administration was created in 1953, by the Federal Government to provide low interest loans to small businesses. However, it appears that the SBA loan programs render benefits, more to the financial institutions that participate in the guaranteed loan programs than to the small business firms. Micro-financing is a new wave started by Yunus in Bangladesh for providing low interest loans, without the requirement of any collateral, to small business entrepreneurs. Further research is needed to assess the efficacy of the system of micro-financing in rendering effective help to small business entrepreneurs. 


\section{AUTHOR INFORMATION}

Dr. RamMohan R. Yallapragada is an Associate Professor of Accounting at Fayetteville State University. He obtained his PhD degree in Accounting from the University of Houston. He holds a CPA certificate from the State of Louisiana. He taught at University of Texas at San Antonio, Nicholls State University, and University of Louisiana, Lafayette before joining FSU. He has published in several journals including Journal of Business and Economic Research, International Business and Economic Research Journal, Journal of Accounting and Finance Research, and Clarion Business and Economic Review. His research areas include Cost Accounting in Healthcare, Accounting irregularities in Fannie Mae, impact of Sarbanes-Oxley Act of 2002 on American corporations and the effect of unprecedented growth in the economies of India and China on global trade. E-mail: ryallapr@uncfsu.edu

Dr. Mohammad Bhuiyan received his PhD degree from University of Florida, two MBA degrees from Georgia State University and Indian Institute of Management, Bangalore. He has also received leadership training from Center for Creative Leadership, Emory University, Duke University, American Council on Education, and Harvard Business School. Dr. Bhuiyan's main teaching and research interests are in the area of entrepreneurship, international business management, and leadership. He has published in several journals including Atlanta Business Journal, Black Issues in Higher Education, Black Enterprise and Savannah Business Journal. Dr. Bhuiyan has been named to the Who's Who in the World, Who's Who in America, Who's Who in Finance and Industry, Who's Who in the South and Southwest and International Who's Who of Professional Management. He is an Endowed Professor of Entrepreneurship and Assistant Dean at School of Business \& Economics at Fayetteville State University. E-mail: mbhuiyan@uncfsu.edu

\section{REFERENCES}

1. Berger, A. and G. Udell (1998). "The Economics of Small Business Finance: The Roles of Private Equity and Debt Markets in the Financial Growth Cycle," Journal of Banking and Finance, 22: pp. 613-673.

2. Brown, Stephanie (2007). "Seven Skills for the Aspiring Entrepreneurs," Business \& Economic Review, Jan-Mar 2007, Vol.53, Issue 2, pp. 16-18.

3. Carland, J. W., F. Hoy, W. R. Boulton and J. C. Carland (1984). "Differentiating Small Entrepreneurs From Small Business Owners: A Conceptualization,” Journal of Business Ethics, Vol. 9, Issue 1, pp. 354359.

4. Carter, Richard B. and Howard Van Auken (2005). "Bootstrap Financing and Owners' Perception of Their Business Constraints and Opportunities," Entrepreneurship \& Regional Development, Vol.17, Issue 2, March 2005, pp. 129-144.

5. Coleman, S. (2000). "Access to Capital and Terms of Credit: A Comparison of Men-Women Owned Small Businesses," Journal of Small Business Management, 38: 37-52.

6. Craig, Ben R., W. E. Jackson, and J. B. Thompson (2009). "The Economic Impact of Small Business Administration's Intervention in the Small Firm Credit Market: A Review of the Research Literature," Journal of Small Business Management, April 2009, Vol. 47, Issue 2, pp. 221-231.

7. Cuba, R., D. DeCenzo and A. Anish (1983). "Management Practices of Successful Female Business Owners," American Journal of Small Business, Vol. 8, Issue 2, 1983, pp. 40-46.

8. De Rugy, V. (2007). "The SBA’s Justification IOU," American Enterprise Institute, Regulation, Spring 2007, pp. 26-84.

9. Douglas, Heather and Pam Martin (2009). "Hailing Small Businesses' Biggest Battlers," NZ Business, Nov. 2009, Vol. 23, Issue 10, p. 17.

10. Farrell, Chris (2006). "Microfinance: Service the Poor Can Bank On," BusinessWeek Online, 5/2/2006, p. 15.

11. Hebert, R. F. and A. N. Link (1982). The Entrepreneur: Mainstream Views and Radical Critiques, $2^{\text {nd }}$ Ed., Praeger, New York, NY.

12. Headd, Brian (2010). "An Analysis of Small Business and Jobs," A Report developed within Small Business Administration, Office of Advocacy, March 2010.

13. Kobe, Kathryn (2007). "How Important are Small Businesses to the United States' Economy?”, Office of Advocacy, Funded research, United States Department of Commerce, Bureau of the Census and International Trade Administration, 2007. 
14. O’Connell, B. (2004). “The FastTrac to Success,” reporting part of research by Neubert, Mitch, H. R. Gibson and C. Longnecker (2004). "Managers Fail to Get Results in Rapidly Changing Organizations: Top 10 Causes," Baylor Business Review, Fall 2004, Vol. 22, Issue1, pp.26-27.

15. Quinn, J. J. (1977). "Personal Ethics and Business Ethics: The Ethical Attitudes of Owners/Managers of Small Businesses," Journal of Business Ethics, Vol. 16, Issue 2, pp.119-129.

16. Resnick, Rosalind (2006). "Extra Effort," Entrepreneur, December 2006, Vol.34, Issue 12, p. 112.

17. Small Business Administration, Office of Advocacy Group (2003). Dynamics of Women-Operated Sole Proprietorships, 1990 - 1998, Washington, DC 2003.

18. Robinson, Tennile M. et al. (2007). "Survival of the Fittest," Black Enterprise, November 2007, Vol. 38, Issue 4, pp. 96-98.

19. Swinney, Jane, Rodney C. Runyan and Patricia Huddleston (2006). "Differences in Reported Firm Performance by Gender: Does Industry Matter?” Journal of Developmental Entrepreneurship, June 2006, Vol. 11, Issue 2, pp. 99-115.

20. Van Auken, H. and R. Carter (1989). “Acquisition of Capital by Small Business,” Journal of Small Business Management, 27: pp. 1-9.

21. Yunus, Muhammad (2007). Creating a World Without Poverty: Social Business and the Future of Capitalism, Public Affairs, Perseus Book Group, New York, NY 2006, p.49.

22. Yunus Muhammad (2008). "Epiphanies: Muhammad Yunus,” Foreign Policy, Jan/Feb 2008, Issue 164, p.29. 